\title{
To What Extent does Employees' Perception of Organizational Justice Influence Their Organizational Citizenship Behaviour?
}

\author{
Lebbaeus Asamani ${ }^{1}$ Abigail, Opoku Mensah ${ }^{2}$ \\ 1. Department of Educational Foundation, University of Cape Coast, Cape Coast, Ghana \\ 2. Abigail Opoku Mensah, Department of Management Studies, School of Business, University of Cape \\ Coast, Cape Coast, Ghana \\ Email of the corresponding author: lebbaeusa@yahoo.com
}

\begin{abstract}
This study investigated how employees' perception of organizational justice affects their Organizational Citizenship Behaviour (OCB). Three dimensions of organizational justice were studied. Organizational tenure of employees was also considered as a mediating variable. Social Exchange Theory and the Norm of Reciprocity were utilized in describing potential relationships because of their association with the concept of fairness and socialization. Data for the study were obtained from 152 employees. The data were analyzed using descriptive statistics, the Pearson's correlation and multiple regression analysis. Hypotheses were tested at the .05 and .01 levels of significance. The results revealed that organizational justice perceptions of employees significantly and positively influenced, and accounted for $6.5 \%$ of the variance in their OCB. Analysis of the degree of relationship of the three sub-categories of organizational justice to OCB indicate that, procedural and interactional justice both related positively and significantly to OCB at the .01 level of significance. Distributive justice, however, did not significantly relate to OCB. A hierarchical regression indicated that distributive justice accounted for only $1.4 \%$ of the variance in OCB. Procedural justice and interactional justice accounted for $3.7 \%$ and $2.1 \%$ respectively. This implies that distributive justice did not have a significant influence on employees' involvement in citizenship behaviour. Employees' organizational tenure did not mediate the relationship between their justice perception and citizenship behavior. The results were discussed in relation to other research findings. Key words: Organizational Justice, organizational citizenship behaviour, perception, social exchange theory.
\end{abstract}

\subsection{Introduction}

In the light of current global competitive business environment, organizations need employees who are willing to exceed their formal job requirements (e.g. Katz, 1964; Organ \& Ryan 1995). Exceeding formal job requirement, commonly called Organizational Citizenship Behaviour (OCB), has received a great deal of research attention (e.g., Dar, 2010; Organ, 1990; Asamani \& Opoku Mensah, 2013). Kegan (1994) observed that today's workers are expected: a) to invent their own work; b) to be self-initiating, self-correcting, self-evaluating; and c) to take responsibility for what happens to them at work. Lawler (1994) states: "In a rapidly changing environment, employees need to rapidly change what they are doing and in some cases, to change the competences that they have in order to perform in new and different ways" (p. 5). In response to these increased demands, employees need to be more proactive in the workplace, and organizations now need employees who are willing to exceed their formal job requirements.

Many terms have been used to describe OCBs, including prosocial organizational behaviour (Brief \& Motowidlo, 1986); extra-role behaviours (Organ, Podsakoff, \& MacKenzie, 2006) and contextual performance (Borman \& Motowidlo, 1993), extra-role behaviour (Van Dyne \& Cummings, 1990) organizational spontaneity (George \& Brief, 1992); and counter-role behaviour (Staw \& Boettger, 1990). Organizational citizenship behaviors (OCB) are behaviors of a discretionary nature that are not part of employees' formal role requirements; however these behaviors contribute to the effective functioning of an organization (Robbins, 2001; Athanasou and King, 2002). OCBs are useful for managing the dependency among employees, thereby increasing the collective outcomes achieved (Netemeyer et al., 1997). Derived from Katz's (1964) notion of extra-role behaviours, (OCBs) have been defined as "individual behaviours that are discretionary, not directly or explicitly recognized by the formal reward system, and that in the aggregate promote the effective functioning of an organization" (Organ, 1988, p. 4).

There have been several categorizations of OCBs, based on common themes. These include altruism or helping behaviour, conscientiousness, organizational compliance, individual initiative and civic virtue (Podsakoff, MacKenzie, Paine, \& Bachrach, 2000). Other researchers (e.g., Williams \& Anderson, 1991) have also divided OCB into two types: behaviour that is directed at individuals in the organization (OCBI) and behaviour that is concerned with helping the organization as a whole (OCBO). Moorman and Blakely (1995) also suggested a four dimension OCB: interpersonal helping, individual initiative, personal industry, and loyal boosterism. Moorman and Blakely's categorization was employed in this study because it is very extensive and captures most extrarole behaviours in organizational settings. Also, it has been widely used by various researchers and has very 
strong reported reliability coefficients and construct validity. OCBs are found related to a number of individual and organizational-level outcomes. They found that OCBs have impact on individual employees via managerial evaluations of employee performance and reward allocation decisions. In addition, OCBs are found to negatively relate to employee withdrawal behaviours, such as turnover intentions, actual turnover, and absenteeism. Besides, OCBs can be relate to a number of organizational-level outcomes, such as productivity, efficiency, reduced costs, customer satisfaction, and unit-level turnover (Podsakoff, Whiting, Podsakoff \& Blume 2009).

Organizational citizenship behaviours are considered to arise, at least in part, from intrinsic motivation including a positive mood state and the need for affiliation or a sense of achievement. Moreover, whether or not the facets of one construct affect facets of the other may depend on the nature of the work as well as the interaction between various workplace and individual variables (Organ, 1988). Notwithstanding, a distinguishing feature is that supervisors cannot require or force their subordinates to perform OCBs. Similarly, employees do not or cannot expect any kind of systematic rewards for these behaviours. However, as Organ (1997) has noted, supervisors do regularly take into account and reward OCBs both directly and indirectly (e.g., preferential treatment, performance ratings, promotions, etc). Another important assertion, especially in Organ's (1988) founding work on $\mathrm{OCB}$, is that these behaviours are often internally motivated, arising from and sustained by an individual's intrinsic need for a sense of achievement, competence, belonging or affiliation. Growing evidence suggests that occurrence of OCB enhances the pleasantness of work settings, and can contribute to increased performance and efficiency (Organ, 1990).

A wide range of employee, task, organizational and leader characteristics are consistently found to predict different types of OCB across a range of occupations (Podsakoff et al, 2000). However, most of these efforts to explain OCB have centered on situational causes, which grow from an employee's interpretation of the nature of his/her job or his/her working differences. One crucial personal factor considered in this study is employees' perception of fairness at the workplace

Workplace justice has been the subject of much recent research (e.g. Greenburg, 1990a) and has been suggested as an organizational variable that could be related to many work outcomes. Recent theory concerning workplace has focused on expanding conceptualizations of fairness to incorporate three dimensions of justice. These are Distributive, Procedural and Interactional justice. Distributive justice is the degree to which rewards are allocated in equitable manner. Procedural justice is the degree to which those affected by such allocation decisions perceive them to have been made according to fair methods and guidelines (Folger \& Greenburg, 1985; Greenburg, 1990b). Interactional Justice describes the fairness in the manner in which the procedures are carried out (Moorman, 1991, p. 852). A more detailed discussion and review of Organizational justice is presented in the next chapter.

\subsection{Problem Definition and Purpose of Study}

Scholars and management practitioners alike are reporting the need for employees to exhibit citizenship behaviours in the workplace in order to solve work-related problems on their own (Gary, 2003). Fairness is a cornerstone of strong work relationships, because employees are highly interested in the manner in which they are treated by their supervisors and organizations. It is logical that employees who operate in an environment of fair treatment will sometimes be afforded opportunities to perform challenging tasks. Whether these employees accept or decline the challenge may depend on the level of their OCB. In light of this discussion, an important question to ask is, "To what extent does organizational justice influence OCB?" Given that occurrence of OCB enhances the pleasantness of work settings, and contribute to performance and efficiency, this brings to mind what steps organizations could take to enhance such actions among employees. According to Konovsky and Folger (1991), the answer seems to involve the perception of fair treatment on the part of employees. Apparently, to the extent that individuals feel they are being treated fairly by their organizations in different ways, the likelihood that they will engage in OCB increases (Moorman, 1991).

Majority of the existing works on the determinants of OCBs have been conducted outside of Africa. It is therefore essential to explore the effects of the various potential antecedents of OCBs under different economic and cultural contexts. Cross-cultural studies of OCB suggest that cultural values can contribute to explanations of variations in job satisfaction, organizational commitment and OCB, both within and between cultures (Moorman \& Blakely, 1995). In view of that, it is essential to find out what the situation is in Ghana since the cultural values of Ghana are different from that of the countries that most of these studies were conducted, and also this construct has been side- stepped (not studied) in Ghana.

\subsection{Objectives of the Study}

The specific objectives of the study include:

1. To find out the extent to which each of the dimensions of organizational justice influences each of the dimensions of OCB.

2. To find out if tenure of employees promotes their OCB. 


\subsection{Significance of the Study}

1. Individuals will benefit by understanding how engaging in OCB enables them to "take control" of their work and initiate "action" toward desired results.

2. Performance practitioners (i.e., trainers, adult educators, performance technologists, and instructional designers) will be better able to design and facilitate interventions, which will lead to successful development of OCB.

3. The study also has an important implication for the selection, training, and development of employees.

4. The findings from the study are very crucial for the smooth operation of any organization.

5. The study builds on previous researches and added to the understanding of organizational behaviour across different cultures.

\subsection{Theoretical Framework and Review of Related Literature}

\subsection{Theoretical Framework: Social Exchange Theory and the Norm of Reciprocity}

The theoretical framework on which this study was based is the Organ's (1988) social exchange theory. Social exchange implies an informal contract between an employee and an organization. OCB has a high level of dependence on socialization; therefore, it is appropriate to consider social exchange theory and the norm of reciprocity for potential constructs that may influence the development of OCB. Blau (1964) describes social exchanges as interactions between two individuals in which one party does another a favour with the expectation of a favour in return, although no time period for this reciprocation is specified. Social exchange involves trusting that the other party will fulfil their obligations (Blau, 1964). Organ (1988) proposed that supervisor fairness leads to employee citizenship because a social exchange relationship develops between employees and their supervisors. When supervisors treat employees fairly, social exchange and the norm of reciprocity (Gouldner,1960) dictate that employees reciprocate, and Organ suggested that organizational citizenship behaviour is one likely avenue for employee reciprocation (Konovsky \& Pugh, 1994).

Blau contrasts social and economic exchange, which parallels a distinction made by Rousseau and Parks (1993) with regards to contracts. Rousseau and Parks described contracts as agreements that create an obligation to do or not do something. According to these authors, contracts vary along a continuum anchored on one end by transactional contracts, which are short-term agreements specifying the limited involvement of each party in the lives and activities of the other, and at the other end by relational contracts, which include the exchange of socioemotional elements, are open-ended, and are often long-term. Relational and transactional contracts respectively correspond to the underlying dynamics of social and economic exchange. Konovsky and Pugh, (1994) therefore suggested that one manifestation of social exchange is reliance on relational contracts and that one manifestation of economic exchange is reliance on transactional contracts. This study focused on the effect of social exchange or relational contract on employees' behaviour, specifically, organizational citizenship behaviour.

2.2 Organizational Justice and Citizenship Behaviour

"Organizational justice is concerned with the ways in which employees determine if they have been treated fairly in their jobs and the ways in which those determinations influence other work-related variables" (Moorman, 1991, p. 845). It refers to fairness in the workplace (Greenberg, 1990), and in particular, employees' perceptions of fairness and how fair treatment influences other employee work-related variables (Moorman, 1991). Recent theory concerning workplace has focused on expanding conceptualizations of fairness to incorporate three dimensions of justice: Distributive, Procedural and Interactional justice.

\subsection{Distributive Justice and $O C B$}

Distributive justice refers to employees' perceptions of the rewards employees receive such as pay or promotions. It is concerned with the fairness of outcomes an employee receives such as pay and promotions (Moorman, 1991). Distributive justice was the earliest of the justice dimensions appearing in the literature. Distributive justice in organizations grew out of more general social action justice based on distributive justice theory (Homans, 1961); equity theory (Adams, 1965); and relative deprivation theory, (Greenberg, 1990). Of the three theories, equity theory is the one most closely aligned with distributive justice (Byrne \& Cropanzano, 2001) and, therefore, is the only theory discussed in this literature review.

Equity theory claims that individuals compare their rewards to their production, and an individual is theorized to be inequitably overpaid if rewards are perceived to exceed production, and the other is theorized to be inequitably underpaid if production exceeds rewards. Equal outcome is theorized to produce equality and hence job satisfaction (Greenberg, 1990). Eventually, equity theory research brought questions related to other organizational practices, particularly those related to the fairness of processes such as how pay plans were administered. The process-oriented concerns shifted the research to "perceived fairness of the policies and procedures used to make decisions (Greenberg, 1990, p. 402). This new era of organizational justice research is known as procedural justice. Although procedural research became dominant, distributive justice research continues. 
Organ (1988a, 1990) suggested a theoretical basis for the relationship between distributive justice and citizenship using equity theory and Blau's (1964) distinction between economic and social exchange. According to equity theory (Adams, 1963), perceptions of an unfair distribution of work rewards relative to work inputs create tension within an individual, and the individual is motivated to resolve the tension. If OCB is considered a work input, then an employee's response to underpayment, perceived as an inequity, could be a deceased exhibition of OCB (Organ, 1988a). In fact, since OCB is discretionary and lies outside employees' formal role requirements, a decrease in OCB would reflect a less radical change to their reward-to -input ratio than a change in in-role task behaviour (Organ, 1990). Also, considering that situational factors often constrain in-role behaviours (Organ, 1977), the choice of decreasing OCB as a response to underpayment would be even more likely.

Organ suggested that the key to understanding how distributive justice influences OCB is to realize that employees often overlay the economic exchanges in their organization with social exchanges. If employees define their relationships with their employers as economic exchanges only, distributive justice will have little, (if any), effect on OCB. Reciprocation in an economic exchange would be limited to in-role behaviours because employees would see little cause to go beyond the specific tenets of the employment contract. However, if employees define their relationships with employers as social exchanges, reciprocation would likely entail behaviours that exist outside of any specific contractual promise. An employee would provide OCB because doing so would be consistent with the positive quality of the employment relationship, not because a contract specified it. An employee may believe that OCB is an appropriate response to distributive justice even though such behaviour is not directly rewarded (Gary, 2003). It was therefore, expected that distributive justice will influence employees OCB positively.

\subsection{Procedural justice and $O C B$}

Procedural justice describes the fairness of the procedures used in determining employee outcomes (Moorman, 1991). Thibaut and Walker (1975) are credited with introducing procedural justice in 1975 through their work in the legal arena with dispute resolution procedures. They suggested that dispute resolution occurs in two stages, a process stage in which information is presented and a decision stage in which a decision is rendered. Through laboratory studies, Thibaut and Walker (1975) "found that verdicts in which participants were given process control (voice) were perceived as more fair and better accepted than decisions in which the participants were denied process control" (Greenberg, 1990, p. 403).

Leventhal, Karuza, and Fry (1980) extended the procedural justice research by adding six criteria as determinants of fair procedures. An individual contrasts an existing situation to a standard or rule, comparing a distribution or procedure to that which he believes would be ideally fair in that situation. They identified six justice rules used by individuals in judging the fairness of procedures-accuracy, representativeness, bias suppression, consistency, ethicality, and correctability (Leventhal et al., 1980).

A review by Greenberg (1990a) identified two components of procedural justice. The first component is fair formal procedures; the presence or absence of procedures believed to be fundamental to the fair distribution of rewards influences fairness perceptions (Leventhal, 1980). Examples of such procedures are those designed to increase employee voice in decisions or to decrease bias and error in decisions. The second component of procedural justice is interactional justice; the term refers to the fairness of the treatment an employee receives in the enactment of formal procedures or in the explanation of those procedures In many cases, the manner in which an employee is treated while a procedure is being carried out can influence its perceived fairness. Therefore, the role of procedural justice is to enhance distributive justice. In the case of OCB, then, the relationship between procedural justice and citizenship could be interpreted through any effect of distributive justice on OCB. However, most research on procedural justice has identified effects independent of distributive justice. For example, Moorman (1991) found that when the two types of justice were measured separately, procedural justice predicted citizenship, but distributive justice did not. These findings suggest that procedural justice may influence OCB independent of any influence it has on perceptions of distributive justice. Procedural justice is instrumental in promoting group concerns because fair procedures communicate the message that the group values each member. Thus, independent of the effect of distributive justice on OCB, procedural justice should also be related to citizenship.

\subsection{Interactional Justice and $O C B$}

Interactional justice refers to the interpersonal treatment employees receive from decision makers and the adequacy with which the formal decision-making procedures are explained (Greenberg, 1990). Bies and Moag (1986) argue that "an allocation decision is a sequence of events in which a procedure generates a process of interaction and decision making through which an outcome is allocated to someone" (Bies \& Moag, 1986, pp. 45-46). They argue that these are two separate processes, one concerning decision procedures and one concerning the enactment of the procedures and each process is subject to fairness considerations (Bies \& Moag, 1986). They focused on the fairness of the communication aspect of interpersonal treatment and criteria that 
people use to judge the fairness of communication during the process of resources allocation. "Their criteria included truthfulness, respect, propriety of questions, and justification, which were subsequently summarized into two categories by researchers: a) clear and adequate explanations, or justifications, for an allocation decision, and b) treatment of recipients with dignity and respect during the implementation of decision procedures" (Bobocel \& Holmvall, 2001, p. 89).

Some researchers view interpersonal justice and informational justice as two separate dimensions of interactional justice (Greenberg, 1990). Interpersonal justice refers to personal treatment such as politeness, dignity, and respect, while informational justice refers to the explanations provided about why certain procedures were followed (Colquitt, 2001). Parker (1998) conducted two studies, one cross-sectional and one longitudinal. Specifically, she found that "employees were more likely to take on additional tasks when they were informed, listened to, and encouraged to speak" (Parker, 1998, p. 849). High quality workplace communication of this nature implies a willingness by the organization and/or supervisor to provide fair treatment by allowing input from employees. This boosts employees' trust in management, which in turn leads to engagement in discretionary behaviour on the part of employees.

In contrast to procedural justice, distributive justice, or the fairness of decision outcomes is the typical metric for judging the fairness of transactional contracts and economic exchange. A norm of distributive fairness implies that the parties to an exchange give benefits with the expectation of receiving comparable benefits in the shortrun. When the conditionality of an exchange is salient, as it is when distributive justice and economic exchange characterize a situation, the expression of feelings like trust is undercut because sufficient extrinsic explanations for the parties' continued participation in the relationship exist. The conditionality of economic exchange also inhibits the development of trust because that development requires evidence of one party's self-sacrifice and responsiveness to another person's needs, which conditional exchanges do not provide (Holmes, 1981; MacNeil, 1985).

2.6 Tenure as a Mediator of Citizenship Behaviour

There are several mediating variables that may mediate the relationship between OCB and other variables of interest. Organizational tenure was considered in this study. Van Dyne et. al. (2000) cited March and Simon (1958), who found out that as tenure increases, individuals develop a better understanding of organizational practices and routines as well as a better idea of their own role within the organizational system. When individuals are involved with organizations for a longer period of time their attitudes (positive or negative) crystallize based on repeated interactions. Given the importance of ongoing relationships to the notion of social exchange, it is expected that tenure in the organization would influence the quality of the relationship with the organization. If over time, members develop good personal relationships with others in the organization and feel as though they are making important contributions to the organization, they will most likely develop a sense of intrinsic motivation and become more attached to the organization (Mathieu \& Zajac, 1990, Rousseau, 1989). On the other hand, if over time, individuals have negative experiences in the organization; these negative feelings most likely become stronger over time and lead to less organizational involvement.

In view of the literature reviewed above, and the aims of this study, the following were hypothesized:

\section{HYPOTHESES:}

$\mathrm{H}_{1}$ : Employees' perception of Organizational Justice will be positively related to their OCB.

$\mathrm{H}_{2}$ (a): Distributive Justice will positively influence OCB.

$\mathrm{H}_{2}$ (b) Procedural Justice will positively influence OCB

$\mathrm{H}_{2}$ (c) Interactional justice will be positively related to OCB

$\mathrm{H}_{3}$ : Organizational tenure will positively influence the relationship between organizational justice and OCB.

\subsection{Methodology}

\subsection{Research Design}

The design used for the study was the survey design.

3.2 Sample and Sampling Procedure

The data for this study were obtained from 152 white-collar and blue-collar employees in ten organizations in the Accra and Tema Metropolis. The respondents were randomly sampled, using the lists of employees obtained from the Human Resources Managers from their various organizations. Respondents included subordinates, supervisors, and middle managers. Top management was not included because they invariably, represent their organization in various capacities. Ninety-five of the respondents were males, and 57 were females, representing $62.5 \%$ and $37.5 \%$ for males and females respectively. The ten organizations consisted of 3 service organizations, 1 manufacturing organization, 2 educational institutions and 4 financial institutions. Different types of organizations were included to ensure greater external validity of the findings.

The ages of the respondents range from 18-56 years, with the average age being 32.38 years and standard deviation of 7.42. A preliminary analysis shows that $32 \%$ of the respondents had been with their organization for 
a period less than a year. Most of the respondents, $(43.4 \%)$ had been with their organizations for a period ranging from $1-5$ years; $19.1 \%$ for $5-10$ years, $5.3 \%$ for $10-15$ years and 9.2 for 15 years or more.

\subsection{Measuring Instrument}

Demographic information was gathered in the first section of the questionnaire including Age of respondents, gender, length of time served with current organization, and level of education. Three dimensions of organizational justice were measured in this study: distributive justice, procedural justice, and interactional justice. The justice scale developed by Moorman (1991) was used in this study. It consists of a five- item dimension measuring perception of distributive justice, and two dimensions measuring Procedural justice. The procedural justice sub-scale consists of six items and nine items for interactional justice respectively. The score for a respondent is the sum of scores across the 20 items. Sample items are: "I always go out of my way to make new employees welcome in the organization"; I always meet or beat deadlines for completing work"; and I show pride when representing the organization in public." All items were on a seven-point response format. It had reported reliabilities above 0.90 (e.g. Moorman \& Blakely, 1995). A reliability coefficient of .92 was obtained in a pilot study using 120 participants, and .91 for the main study.

The four dimensional self-rating scale developed by Moorman and Blakely (1995) was used to obtain OCB data. The four dimensions consisting of 19 items are interpersonal helping (5 items), individual initiative (5 items), personal industry (4 items), and loyal boosterism ( 5 items). For this study, the alpha coefficient was .82. All items were scored on seven-point response format, therefore the maximum score on this scale is 133 and the minimum is 19 for each respondent.

\subsection{Research Procedure}

The questionnaires were personally distributed to participants, with the assistance of delegates from the organizations. The Human Resources Managers of some organizations offered to distribute the questionnaires themselves. The completed questionnaires were collected within a week of distribution for analyses.

3.4 Data analysis and procedure

Each questionnaire was examined for completeness and two eliminated because whole sections were blank. Raw data were initially entered into an SPSS for Windows, Version 16.0, and was used to transform single-item scores of each of the scales into a composite score of means on each scale for all respondents. These scores were subsequently used as the basis for further analysis. The SPSS "Explore" descriptive statistics procedure was used to capture the means, mode, and standard deviation. A scale reliability analysis was performed to evaluate the reliability of the scales. Correlations were run to determine the relationship between the independent variables and the dependent variable. Thereafter, regression analyses were performed to determine the amount of variance in the dependent (criterion) variable accounted for by each predictors. Hierarchical regressions were run to determine the effect of predictor and mediator variables on the criterion variable. Baron and Kenny's (1986) three step hierarchical regression procedure was used to test for mediation variables.

\subsection{Results}

Organizational justice related positively to organizational citizenship behaviour $(r=.254, p<.01)$. This supports or confirms the research hypothesis: "Organizational justice will relate positively to OCB." The coefficient of determination $\left(\mathrm{r}^{2}=0.065\right)$, suggests a weak association $(6.5 \%)$, though significant, relationship between overall justice perception of employees and OCB.

\subsection{Table 1: Correlation coefficients of Organizational Justice, sub-categories of Justice and OCB}

\begin{tabular}{lllll}
\hline Variable & $\mathrm{R}$ & $\mathrm{R}^{2}$ & Sig. (1-tailed) & Remark \\
\hline Organizational Justice & .254 & .065 & .001 & Sig \\
Procedural Justice & .224 & .050 & .003 & Sig \\
Interactional Justice & .259 & .067 & .001 & Sig \\
Distributive Justice & .119 & .014 & .072 & Non sig \\
\hline \hline
\end{tabular}

The degree of relationship of the three sub categories of organizational justice to OCB was also sought. The results indicate that, procedural $(\mathrm{r}=.224)$ and interactional $(\mathrm{r}=.259)$ justice both relate positively and significantly to OCB at the .01 level of significance. Distributive justice, however, did not significantly relate to OCB; the relationship, though positive $(\mathrm{r}=.119)$.

The hierarchical regression presented in the table below indicates that distributive justice accounted for only $1.4 \%$ of the variance in OCB. Procedural justice accounted for the highest variance in OCB (3.7\%), and interactional justice accounted for $2.1 \%$. 
Table 2: Model Summary of hierarchical regression of OCB on the sub-categories of organizational justice

\begin{tabular}{|c|c|c|c|c|c|c|c|}
\hline 1 & $.119^{\mathrm{a}}$ & .014 & .008 & 16.885 & .014 & 2.157 & .144 \\
\hline 2 & $.225^{b}$ & .051 & .038 & 16.625 & .037 & 5.731 & .018 \\
\hline
\end{tabular}

a. Predictors: (Constant), Distributive Justice

b. Predictors: (Constant), Distributive Justice, Procedural Justice

c. Predictors: (Constant), Distributive Justice, Procedural Justice, Interactional Justice

\section{Test for mediator variables}

Hypothesis 3 requires a test of mediation of relationship between organizational justice and OCB. Accordingly, Baron and Kenny's (1986) hierarchical regression procedure was used. The result indicates that organizational justice has no significant relationship with organizational tenure $(\mathrm{p}=.871)$, hence, does not mediate the relationship between organisational justice and OCB.

\subsection{Discussion of Results}

It was predicted that organizational justice will relate positively to OCB, which was supported by the findings of the study. This result was anticipated, because similar results were obtained in other empirical research. Gary (2003) observed that an employee would provide OCB because doing so would be consistent with the positive quality of the employment relationship, not because a contract specified it. Organ and Konovsky (1989) also postulated that employees' perception of the degree of fairness in the workplace might be particularly important in the emergence of OCBs, since fair treatment is expected to result in a dramatic shift in the employees' mindsets concerning the nature of their relationship with their respective organizations.

The relative importance of each sub-category of organizational justice was further explored. An employee may believe that OCB is an appropriate response to fair distribution of resources, even though such behaviour is not directly rewarded (Gary, 2003). It was therefore expected that distributive justice will influence OCB positively. The results from the study however, did not support this expectation. This came as a surprise, but a tenable explanation for this may be that employees define their relationship with their employers as an economic exchange. Organ (1990) cited Blau (1964) to explain why distributive justice might not relate to OCB. Blau asserts that, economic exchanges motivate behaviour designed to fulfil the formal contract of employment.

The findings of the study also indicate that, apart from distributive justice that did not relate to OCB, procedural and interactional justices (managerial justice) both have positive effect on $\mathrm{OCB}$, with interactional justice having a stronger influence. When employees receive quality interpersonal treatment from decision- makers, and formal decision-making procedures are adequately explained, they are motivated to go beyond formal job requirements. The results indicate that interactional justice has direct, (not indirect) influence on OCB. Interactional justice independently, without a mediating variable, influences employees' trust in management as well as OCB. These findings support, or agree with Malatesta and Byrne's (1997) study. They found that employees' interactional justice perceptions were related to behaviours directed at the supervisor, and those employees trusted by the supervisor (i.e. those who have good interpersonal relationship with the supervisor), are offered more opportunities and feel obligated to reciprocate by performing activities above and beyond written in-role job descriptions.

Contrary to the expectation that organizational tenure will influence the relationship between organizational justice and OCB, the result did not show any significant relationships. According to Van Dyne et. al (1990), when individuals are involved with organizations for a longer period of time their attitudes (positive or negative) crystallize based on repeated interactions. Given the importance of ongoing relationships to the notion of social exchange, it was expected that tenure in the organization would influence the quality of the relationship within the organization. The non-influential nature of employees' tenure they might not have developed good personal relationships with others in the organization or feel as though they were making important contributions to the organization. They therefore did not develop a sense of intrinsic motivation to become more attached to the organization (Mathieu \& Zajac, 1990, Rousseau, 1989). The lack of relationship here may also be due to the fact that most job offers in Ghana are not attractive enough to motivate employees to go beyond formally prescribed roles, irrespective of the number of years they spend in an organization. Employees feel trapped because there are no much job avenues for them to move to even if they are not satisfied with their current organizations. The employment relationship therefore, becomes merely transactional. 
In conclusion, it is essential to acknowledge that employees are the most essential resource of any organization. For any organization to survive in the current global trend in any industry, the employees need to be treated with care and respect. Management-employee relationship must be very cordial, and employees' quality of interpersonal relationship needs to be enhanced and taken seriously.

\section{References}

Adams, J. S. (1965). Inquiry in social exchange. In L. Berkowitz (Ed.), Advances in experimental psychology (Vol. 2, pp. 267-299). New York: Academic Press.

Adams, J. S., (1963), 'Towards an understanding of inequity', Journal of Abnormal and Social Psychology, 67; 87-103.

Asamani, L. \& Opoku Mensah, A.(2013) The Influence of Employees' Self-Efficacy on Their Quality of Work Life: The Case of Cape Coast, Ghana, International Journal of Business and Social Sciences, Vol. 4 No. $2 ; 195-205$.

Athanasou, M.G.C., \& King J. N. (2002). Job satisfaction and organizational citizenship behavior: a study of Australian human-service professionals. J. Man. Psychol., 17 (4): 287-297.

Baron, R.M.,\& Kenny, D.A. (1986). "The moderator-mediator variable distinction in social psychological research: Conceptual, strategic, and statistical considerations". Journal of Personality and Social Psychology, 51; 1173-1182.

Bies, R. J. (2001). Interactional (in)justice: The sacred and the profane. In J. Greenberg \& R. Cropanzano (Eds.), Advances in Organizational Justice (pp. 89-118). Stanford, CA: Stanford University Press.

Bies, R. J., \& Moag, J. S. (1986). Interactional justice: “Communication criteria of fairness”. In R. J. Lewicki, B. H. Sheppard, \& M. H. Bazerman (Eds.), Research on Negotiation in Organizations (Vol. 1, pp. 43-55). Greenwich, CT: JAI Press Inc.

Blau, P. M. (1964). Exchange and power in social life. New York: John Wiley \& Sons.

Borman, W. C., \& Motowidlo, S. J. (1993). Expanding the criterion domain to include elements of contextual performance. In N. Schmitt, \& W. C. Borman (Eds.), Personnel selection in organizations (pp. 71-98). San Francisco: Jossey-Bass.

Bobocel, D. R., \& Holmvall, C. M. (2001). Are interactional justice and procedural justice different? Framing the debate. In S. Gilliland, D. Steiner, \& D. Skarlicki (Eds.), Theoretical and cultural perspectives on organizational justice (pp. 85-108). Greenwich, CT: Information Age Publishing.

Brief, A. P., \& Motoowidlo, S. J. (1986). "Prosocial organizational behaviours". Academy of Management review, 11: 710-725.

Colquitt, J. A. (2001). "On the dimensionality of organizational justice: A construct validation of a measure". Journal of Applied Psychology, 86(3), 386-400.

Cropanzano, R., \& Ambrose, M. L. (2001). Procedural and distributive justice are more similar than you think: A monistic perspective and a research agenda. In J. Greenberg \& R. Cropanzano (Eds.), Advances in Organizational Justice (pp. 119-151). Stanford, CA: Stanford University Press.

Dar, O. L., (2010). Trust in Co-Workers and Employee Behaviours at Work, International Review of Business Research Papers: 6 (1), 194-204

Folger, R. (1977). "Distributive and procedural justice: Combined impact of voice and improvement on experienced inequity". Journal of Personality and Social Psychology, 35,108-119.

Folger, R. \& Konovsky, M.A. (1989), "Effects of Procedural and Distributive Justice on Reactions to Pay Decisions", Academy of Management Journal, 32, 115-130.

Folger, R., \& Greenberg, J. (1985). Procedural justice: An interpretive analysis of personnel systems. In K. M. Rowland \& G. R. Ferris (Eds.), Research in ersonnel and human resources management (Vol. 3, pp. 141-183). Greenwich, CT: JAI.

Gary J. Ruder (2003). "The relationship among organizational justice,trust and role-breadth self-efficiency". $A$ dissertation submitted to the faculty of Virginia Polytechnic Institute and State University.

George, J.M., Brief, A.P. 1992. "Feeling good-doing good": A conceptual analysis of the mood at workorganizational spontaneity relationship. Psychological Bulletin, 112: 310-329.

Gouldner, A. W. (1960). "The norm of reciprocity": A preliminary statement. American Psychological Review, 25(2), 161-178.

Greenberg, J. (1990), “Organizational Justice: Yesterday, Today and Tomorrow”, Journal of Management, 16 , 399-432.

Holmes, J.G.1981. The exchange process in close relationships: Micro-behaviour and macro-motives. In M.J. Lerner\& S.C. Lerner (Eds). The justice motive in social behaviour: 261-284. New York: Plenum.

Homans, G. C. (1961). Social behaviour: Its elementary forms. New York: Harcourt, Brace, \& World.

Katz, D. (1964). "The motivational basis of organizational behaviour". Behavioural Science, 9: 131-133. 
Kegan, R. (1994). In over our heads. Cambridge, Massachusetts: Harvard University Press.

Konovsky, M. (2000). "Understanding procedural justice and its impact on business organizations". Journal of Management, 26(3), 489-511.

Konovsky, M. A., \& Pugh, S. D. (1994). "Citizenship behaviour and social exchange”. Academy of Management Journal, 37(3), 656-669.

Konovsky, M.A., \& Folger, R. (1991). The effects of procedural and distribution justice on organizational citizenship behaviour. Paper presented at the annual meeting of the Academy of Management, Miami.

Lawler, E. E. I. (1994). Motivation in work organizations. San Francisco: Jossey-Bass Publishers.

Leventhal, G. S. (1980). What should be done with equity theory? In K. J. Gergen, M. S.

Leventhal, G. S., Jurgis Karuza, J., \& Fry, W. R. (1980). Beyond fairness: A theory of allocation preferences. In G. Mikula (Ed.), Justice and Social Interaction (pp. 167-218). New York: Springer-Verlag.

Lind, E. A. (2001). Fairness heuristic theory: Justice judgments as pivotal cognitions in organizational relations. In J. Greenberg \& R. Cropanzano (Eds.), Advances in Organizational Justice (pp. 56-88). Stanford, CA: Stanford University Press.

March J G, Guetzkow H \& Simon H. (1958) Organizations. New York: John Wiley \& Sons; 262

MacNeil, I.R. (1985). "Relational contracts: What we do and do not know". Wisconsin Law Review: 483-535.

Malatesta, R. M., \& Byrne, Z. S. (1997). The impact of formal and interactional justice on organizational outcomes. Paper presented at the Annual Meeting of the Society for Industrial and Organizational Psychology, St Louis.

Mathieu, J. E., \& Zajac, D. (1990). A review and meta-analysis of the antecedents, correlates, and consequences of organizational commitment. Psychological Bulletin, 108, 171-194.

Moorman R. H, \& Blakely, G. L (1992). “A preliminary report on a new measure of organizational citizenship behaviour”. Southern Management Association Proceedings: 185-187.

Moorman R. H. \& Blakely, G. L. (1995). "Individualism-Collectivism as an individual difference predictor of organizational citizenship behaviour". Journal of organizational Behaviour, 16 (2) , 127-142.

Moorman, R.H. (1993), “The Influence of Cognitive and Affective Based Job Satisfaction on the Relationship Between Satisfaction and Organizational Citizenship Behaviour", Human Relations, 46, 759-76.

Moorman, R.H. (1991). "Relationship between organizational justice and organizational citizenship behaviours". Do fairness perceptions influence employee citizenship? Journal of Applied Psychology, 76: 845-855.

Netemeyer, R. G., Boles, J. S., McKee, D. O., \& McMurrian, R. (1997). “An investigation into the Antecedents of organizational citizenship Behaviour in a personal setting context". Journal of Marketing. Vol.61.No3, 85-98.

Organ, D., Podsakoff, P. \& MacKenzie, S., 2006. Organizational citizenship behaviour: Its nature, antecedents, and consequences, Thousand Oaks, CA: Sage Publications.

Organ, D.W. (1988a). Organizational Citizenship Behaviour: The "good soldier" syndrome. Lexington, MA" Lexington Books.

Organ, D. W. (1977) A reappraisal and reinterpretation of the satisfaction-causes-performance hypothesis. Academy of Management Review, 2, 46-53 (1977).

Organ, D.W. (1990). "The motivational basis of organizational citizenship behaviour". In B.M. Staw \& L.L. Cummings (Eds.), Research in organizational behaviour, vol. 12: 43-72. Greenwich, CT: JAI Press.

Organ, D.W., \& Konovsky, M. (1989). "Cognitive versus affective determinants of organizational citizenship behaviour". Journal of Applied Psychology, 74: 157-164.

Organ, D. W., \& Ryan, K. (1995). A meta-analytic review of attitudinal and dispositional predictors of organizational citizenship behavior. Personnel Psychology, 48(4), 775-802.

Parker, S. K. (1998). "Enhancing role breadth self-efficacy": The roles of job enrichment and other organizational interventions". Journal of Applied Psychology, 83(6), 835-852.

Podsakoff, P.M., Mackenzie, S.B., Paine, J.B., And Bachrach, D.G. (2000), “Organizational Citizenship Behaviours: A Critical Review of the Theoretical and Empirical Literature and Suggestions for Future Research", Journal of Management, 26(3), 513-63.

Robbins SP (2001). Organizational Behavior, New York: Prentice Hall.

Rousseau, D.M. (1989) Psychological and implied contracts in organizations. Employee Rights and Responsibilities Journal, 2, 121-139.

Rousseau, D.M., \& Parks, J.M. (1993). "The contracts of individuals and organizations”. In B.M. Staw \& L. L. Cummings (Eds.), Research in organizational behaviour, vol. 15: 1-43. Greenwich, C.T: JAI Press.

Cropanzano R., \& Byrne S. Z. (2001). A paper presented as a poster session for the fifteenth annual conference of the society for 110 Psycho. in New Corleans ,L A, April 13-16.

Staw, B.M., \& Boettger, R.D. (1990). "Task revision: A neglected form of work performance". Academy of Management Journal, 33: 534-559. 
Thibaut, J., \& Walker, L. (1975). Procedural justice: A psychological analysis. Hillsdale, NJ: Lawrence Erlbaum Associates.

Tyler, T. R. \& Bies, R. J. (1990). 'Beyond formal procedures: the interactional context of procedural justice.'In: J. S. Cornell (ed), Applied Social Psychology of Organizational Settings (pp 77-98). Hillside,NJ: Lawrence Erlbaum Associates.

Van den Bos, K., Lind, E. A., \& Wilke, H. A. M. (2001). The psychology of procedural and distributive justice viewed from the perspective of fairness heuristic theory. In R. Cropanzano (Ed.), Justice in the workplace: From theory to practice (Vol. 2, pp. 49-66). Mahwah, NJ: Lawrence Erlbaum Associates.

Van Dyne, L., \& Cummings, L.L. 1990. Extra-role behaviours: In pursuit of construct and definitional clarity. Paper presented at the annual meeting of the Academy of Management, San Francisco.

Williams, L. J., \& Anderson, S. E. (1991). Job satisfaction and organizational commitment as predictors of organizational citizenship and in-role behaviors. Journal of Management, 17, 601-617. 
This academic article was published by The International Institute for Science, Technology and Education (IISTE). The IISTE is a pioneer in the Open Access Publishing service based in the U.S. and Europe. The aim of the institute is Accelerating Global Knowledge Sharing.

More information about the publisher can be found in the IISTE's homepage: http://www.iiste.org

\section{CALL FOR PAPERS}

The IISTE is currently hosting more than 30 peer-reviewed academic journals and collaborating with academic institutions around the world. There's no deadline for submission. Prospective authors of IISTE journals can find the submission instruction on the following page: http://www.iiste.org/Journals/

The IISTE editorial team promises to the review and publish all the qualified submissions in a fast manner. All the journals articles are available online to the readers all over the world without financial, legal, or technical barriers other than those inseparable from gaining access to the internet itself. Printed version of the journals is also available upon request of readers and authors.

\section{IISTE Knowledge Sharing Partners}

EBSCO, Index Copernicus, Ulrich's Periodicals Directory, JournalTOCS, PKP Open Archives Harvester, Bielefeld Academic Search Engine, Elektronische Zeitschriftenbibliothek EZB, Open J-Gate, OCLC WorldCat, Universe Digtial Library, NewJour, Google Scholar

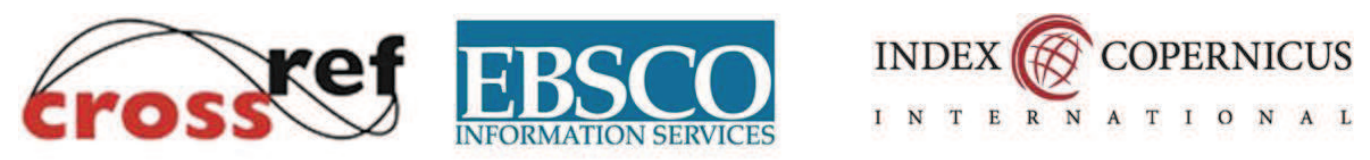

\section{(D) ULRICHSWEB}

JournalTOCs

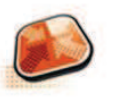

PKP | PUBLIC KNOWLEDGE PROJECT
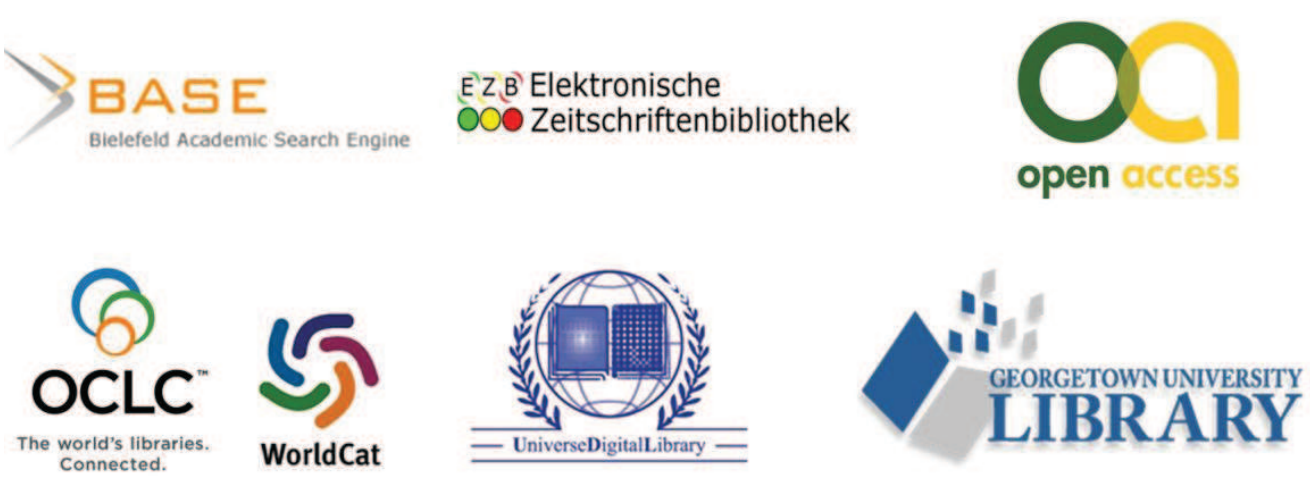